\title{
The Influence of Fundamental Factors of Macroeconomics Against Price Earning Ratio through Dividend Payout Ratio for LQ.45 Non-Banking Companies
}

\author{
Rudi Sanjaya ${ }^{1)}$; Krida Puji Rahayu ${ }^{2)}$ \\ ${ }^{1,2)}$ Pamulang University, dosen02253@unpam.ac.id
}

ARTICLES
INFORMATION ABSTRACT

\section{JURNAL SEKURITAS}

(Saham, Ekonomi, Keuangan dan Investasi )

Vol.4, No.1, September 2020 Halaman : $80-95$

(C) LPPM \& Prodi Manajemen UNVERSITAS PAMULANG

\section{ISSN (online) : 2581-2777} ISSN (print) : : 2581-2696

\section{Keyword :}

Return on Equity (ROE); Debt to Equity Ratio (DER); Net Profit Margin (NPM); Inflation; Dividend Payout Ratio (DPR); and Price Earning Ratio (PER).

JEL. classification :

C33, G21, G24, N15, N25

\section{Contact Author :}

PRODI MANAJEMEN UNPAM

JL.Surya Kencana No.1 Pamulang

Tangerang Selatan - Banten

Telp. (021) 7412566, Fax (021) 7412491 Email :

sekuritas@unpam.ac.id
This study attempts to examine and analyze fundamental factors and to influence Dividend Payout Ratio and its impact on the company to companies 2014-2017 lq-45 period. In the form of financial report data obtained from the Indonesia stock exchange (IDX). The sample as many as 19 companies meet criteria. Analysis method data using analysis the linear regression and Path analysis. The data shows that the results of the analysis of its ROE and DER had an influence on Dividend Payout Ratio. NPM and The Inflation Rate has not been affecting The Dividend Payout Ratio. ROE, NPM, and The Inflation Rate has not been affecting PER. ROE, DER, NPM, and The Inflation Rate influential simultaneously against the Dividend Payout Ratio. The Dividend Payout Ratio to depend on the value of PER. There is no cause is an indirect effect between ROE, DER, NPM, and Inflation to PER. 


\section{A. INTRODUCTION}

The Indonesian stock exchange or the capital market continues to develop every year. Along with its development, it has become an effective means of accelerating financial growth, especially for any company that goes public. Currently the government is introducing and providing insight into the capital market to the public so that there will be a willingness and awareness to invest, and want to make this a lifestyle for people to take advantage of business opportunities.

Investing in the capital market, of course, investors must think rationally in dealing with trading on the Indonesia Stock Exchange. Meanwhile, for investors, the capital market allows investors to have healthy companies and high growth prospects, such as in the LQ45 index.

The LQ45 index is a stock market index and the Indonesia Stock Exchange which consists of companies that meet certain criteria, namely:

1. Including top 60 the market capitalization highest in 1-2 months

2. Including top 60 company with the transaction highest dipasar regular 12 months

3. Has been listed at indonesia stock exchange for at least 3 months

4. Having financial condition, growth prospects and transactions are high.

In general, investors expect benefits from their investment, which can be in the form of capital gains or dividends. Dividends represent the share of net profit after tax that is distributed to shareholders. The company's dividend policy is reflected in DPR. DPR shows the share of profit distributed as dividends. DPR can affect investment decisions to be invested by investors, if the company's financial condition is good, the company will set a high DPR.

Fundamental factors for the analysis of "financial statements" are optimal for investors if investors can further analyze them through financial ratio analysis. Macroeconomics measurabled by many indicators such as inflation, interest rates, foreign exchange rates, money supply, GDP, and political and economic indicators. The macroeconomic variable used in this study is inflation. The opinion of Irham (2014: 67) states that inflation is an event that describes a situation and conditions where the price of goods has increase and the worth of the currency has weakened.

Table 1.1

Inflation in indonesia per december 2014-2017

\begin{tabular}{|c|c|}
\hline Year & Inflation Rate (\%) \\
\hline 2014 & 8.36 \\
\hline 2015 & 3.35 \\
\hline 2016 & 3.02 \\
\hline 2017 & 3.61 \\
\hline
\end{tabular}

S0urce: https://www.bi.go.id/id/moneter/inflasi/data/default.aspx

Inflation in the period 2014-2017, tend to fall a period of 2014 as much as $8.36 \%$ and periods $20173,61 \%$. As much aslt means, the smaller inflation is greater level of Dividend Payout Ratio.

The indicators of the prosperity of the shareholders can be seen from the ROE. Irham (2012: 98) states that ROE is the ratio used to examine the extent to which a company uses its resources to be able to provide ROE. This ratio is very important for shareholders to determine the effectiveness of the efficiency of their own capital management and to measure the level of return on investment that has been made by the company's shareholders. 
Kuniawan (2016), argues that the company's debt ratio as Debt to Equity Ratio (DER) reflects the company's ability to fulfill all of its obligations as shown by several parts of its own capital used to pay debt. An increase in debt can affect the size of the net profit available to shareholders, including dividends earned because the obligation to pay debt is more important than dividend distribution.

Hery (2015: 235) argues that "Net Profit Margin (NPM)" is a ratio for gauging net income percentage on sales of net, this ratio is calculation by dividing net income to net sales. The higher NPM guide the higher efficiency, so this variable be important to be considered.

Then, the table of the Dividend Payout Ratio Growth in non-banking LQ45 companies:

Table 1.2

Dividend Payout Ratio Growth

\begin{tabular}{|c|c|c|c|c|}
\hline \multirow{2}{*}{$\begin{array}{c}\text { Code } \\
\text { Company }\end{array}$} & \multicolumn{2}{|r|}{ Dividend } & \multirow{2}{*}{$\frac{\text { Payout }}{2016}$} & \multirow{2}{*}{$\begin{array}{c}\text { Ratio } \\
2017\end{array}$} \\
\hline & 2014 & 2015 & & \\
\hline ADRO & 43.72 & 49.89 & 30.16 & 52.58 \\
\hline AKRA & 62.80 & 45.74 & 47.39 & 106.69 \\
\hline ASII & 45.59 & 49.54 & 44.87 & 39.67 \\
\hline GRGM & 28.67 & 77.73 & 74.92 & 64.52 \\
\hline HMSP & 86.45 & 99.89 & 98.16 & 98.50 \\
\hline ICBP & 49.71 & 49.75 & 49.88 & 49.76 \\
\hline INDF & 49.72 & 49.70 & 49.79 & 49.92 \\
\hline INKP & 12.21 & 4.19 & 6.03 & 9.77 \\
\hline INTP & 94.29 & 35.07 & 88.36 & 138.55 \\
\hline ITMG & 79.19 & 99.26 & 27.94 & 118.01 \\
\hline KLBF & 43.14 & 44.44 & 44.84 & 48.75 \\
\hline PTBA & 37.09 & 32.79 & 32.79 & 16.40 \\
\hline SCMA & 70.41 & 79.66 & 71.11 & 82.36 \\
\hline SRIL & 17.97 & 6.84 & 6.99 & 13.63 \\
\hline SSMS & 30.01 & 64.15 & 30.01 & 30.01 \\
\hline UNTR & 64.95 & 66.89 & 10.66 & 65.65 \\
\hline UNVR & 44.67 & 99.88 & 99.69 & 99.67 \\
\hline WIKA & 16.41 & 17.80 & 25.08 & 17.74 \\
\hline WSKT & 19.89 & 20.01 & 28.35 & 18.48 \\
\hline Rata-Rata & 47.20 & 52.27 & 45.63 & 58.98 \\
\hline
\end{tabular}

Source: Data Processed by Compiler

Then, the table of the Price Earning Ratio (PER) development in non-banking LQ45 companies:

Table 1.3

Development of Price Earning Ratio (PER)

\begin{tabular}{|c|r|r|r|r|}
\hline \multirow{2}{*}{$\begin{array}{c}\text { Code } \\
\text { Company }\end{array}$} & \multicolumn{4}{|c|}{ PER } \\
\cline { 2 - 5 } & $\mathbf{2 0 1 4}$ & $\mathbf{2 0 1 5}$ & \multicolumn{1}{c|}{$\mathbf{2 0 1 6}$} & \multicolumn{1}{|c|}{$\mathbf{2 0 1 7}$} \\
\hline ADRO & 9.27 & 7.83 & 14.96 & 9.09 \\
\hline AKRA & 20.29 & 27.41 & 22.65 & 21.17 \\
\hline ASII & 15.56 & 16.79 & 22.28 & 17.8 \\
\hline GRGM & 21.67 & 16.44 & 20.04 & 22.32 \\
\hline HMSP & 29.48 & 42.2 & 36.79 & 43.42 \\
\hline
\end{tabular}




\begin{tabular}{|r|r|r|r|r|}
\hline ICBP & 27.67 & 26.18 & 26.48 & 27.34 \\
\hline INDF & 14.67 & 15.31 & 16.11 & 16.06 \\
\hline INKP & 16.60 & 4.10 & 20.86 & 13.10 \\
\hline INTP & 18.57 & 18.86 & 13.51 & 43.45 \\
\hline ITMG & 6.32 & 7.43 & 15.81 & 6.83 \\
\hline KLBF & 43.27 & 30.87 & 31.28 & 33.39 \\
\hline PTBA & 13.65 & 5.12 & 20.54 & 6.33 \\
\hline SCMA & 34.72 & 29.75 & 26.57 & 24.87 \\
\hline SRIL & 8.58 & 9.42 & 5.51 & 8.43 \\
\hline SSMS & 25.61 & 33.11 & 44.72 & 18.15 \\
\hline UNTR & 10.17 & 16.41 & 19.01 & 17.84 \\
\hline UNVR & 19.00 & 48.24 & 46.74 & 60.89 \\
\hline WIKA & 42.35 & 25.97 & 39.54 & 11.57 \\
\hline WSKT & 84.55 & 21.63 & 27.78 & 7.73 \\
\hline Rata-Rata & $\mathbf{2 4 . 3 1}$ & $\mathbf{2 1 . 2 1}$ & $\mathbf{2 4 . 3 8}$ & $\mathbf{2 1 . 5 7}$ \\
\hline
\end{tabular}

Source: Data Processed by Compiler

Sundana (2009) Price Earning Ratio (PER) is a ratio that measures how investors assess the company's future growth prospects, and is reflected in the stock price paid by investors for every rupiah of profit earned by the company. companies with high growth rate opportunities usually have high PER as well, and this shows that the market expects profit growth in the future.

Based on the description of the problem above, the research problems can be formulated as follows:

1. Does Return on Equity affect the Dividend Payout Ratio in non-banking LQ45 companies?

2. Does the Debt to Equity Ratio influence the Dividend Payout Ratio in non-banking LQ45 companies?

3. Does Net Profit Margin affect the Dividend Payout Ratio in non-banking LQ45 companies?

4. Does inflation affect the dividend payout ratio in non-banking LQ45 companies?

5. Do Return on Equity, Debt to Equity Ratio, Net Profit Margin, and Inflation simultaneously affect the Dividend Payout Ratio in non-banking LQ45 companies?

6. Does the Dividend Payout Ratio affect PER in non-banking LQ45 companies?

7. Is there an indirect influence between Return on Equity and PER in non-banking LQ45 companies?

8. Is there an indirect influence between the Debt to Equity Ratio and the effect on PER in non-banking LQ45 companies?

9. Is there an indirect effect between Net Profit on PER of non-banking LQ45 companies?

10. Is there an indirect influence between inflation and PER in non-banking LQ45 companies? 


\section{B. LITERATURE REVIEW}

\section{Framework of Thinking}

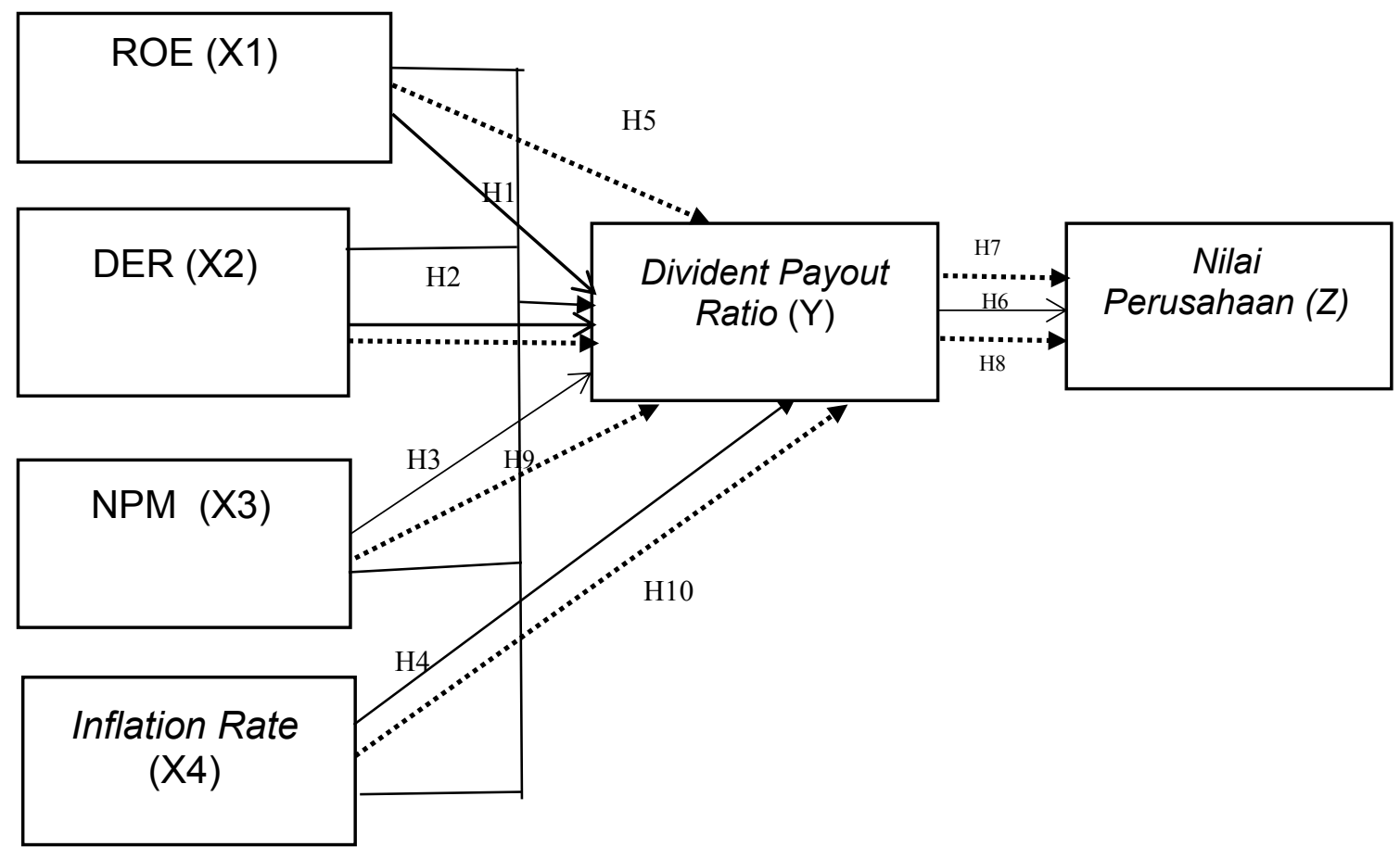

Figure 2.1 Framework of Thinking

\section{Information:}

\section{Direct effect (DE) ( $\longrightarrow$ )}

Meanwhile, the direct effect (DE) of $X 1, X 2, X 3$, and $X 4$ on $Y$ and from $Y$ to $Z$, or more simply can be presented as follows:

$$
\begin{aligned}
& \mathrm{X} 1 \rightarrow \mathrm{Y} \\
& \mathrm{X} 2 \rightarrow \mathrm{Y} \\
& \mathrm{X} 3 \rightarrow \mathrm{Y} \\
& \mathrm{X} 4 \rightarrow \mathrm{Y} \\
& \mathrm{Y} \rightarrow \mathrm{Z}
\end{aligned}
$$

Indirect effect (IE) $(. . . . . . . . . . . . . . \rightarrow$ )

While the indirect effect is from $X 1$ to $Z$ through $Y$, from $X 2$ to $Z$ through $Y, X 3$ to $Z$ through $Y, X 4$ to $Z$ through $Y$ or more simply can be presented as follows:

$$
\begin{aligned}
& \mathrm{X} 1 \rightarrow \mathrm{Y} \rightarrow \mathrm{Z} \\
& \mathrm{X} 2 \rightarrow \mathrm{Y} \rightarrow \mathrm{Z} \\
& \mathrm{X} 3 \rightarrow \mathrm{Y} \rightarrow \mathrm{Z} \\
& \mathrm{X} 4 \rightarrow \mathrm{Y} \rightarrow \mathrm{Z}
\end{aligned}
$$

\section{RESEARCH METHODOLOGY}

The population in this study were non-banking LQ45 companies. The total population is 45 companies from 2014-2017. The non-banking LQ45 company has provided financial reports that can be seen by the public.

This study uses panel data, namely data using cross section data (19 companies) and time series data or based on time sequences (from 2014 - 2017). The test used is the classic assumption test and hypothesis testing using the eviews version 9 application and path analysis using the sobel test. 


\section{RESULTS AND DISCUSSION}

Table 4.1

Descriptive Statistics Results Independent Variable (X) ROE, DER, and NPM Dependent Variable (Y) DPR and Variable (Z) Price Earning Ratio (PER)

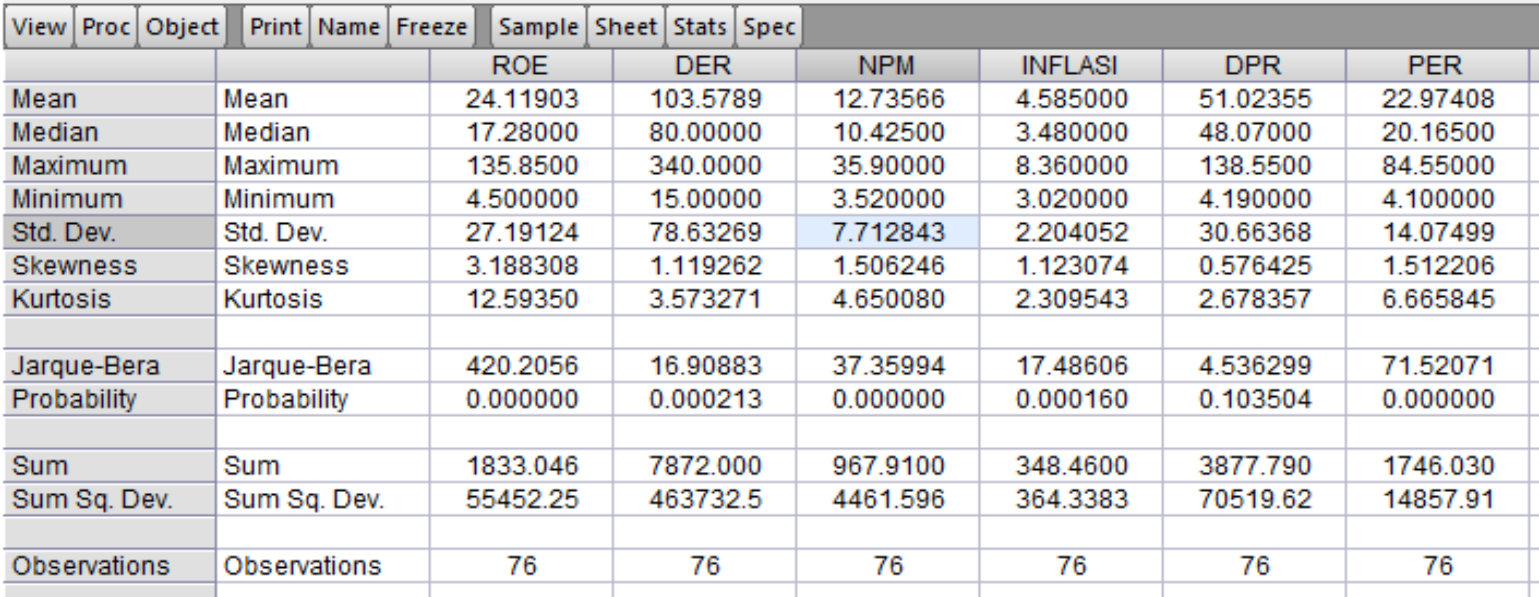

Source: Research data processed 2020 (Eviews Version 9)

Table 4.1 is a table of descriptive statistical test results from independent variables, namely Return on Equity, Debt to Equity Ratio, Net Profit Margin, and Inflation. While the dependent variable is the Dividend Payout Ratio against Price Earning Ratio. The table describes the descriptive statistics of 19 companies in LQ45 non-banking companies. The data was taken in 2014 - 2017.

Common Effect Model Test

Table 4.2 Common Effect Model

Dependent Variable: DPR

Method: Panel Least Squares

Sample: 20142017

Periods included: 4

Cross-sections included: 19

Total panel (balanced) observations: 76

\begin{tabular}{lrlrr}
\hline \hline \multicolumn{1}{c}{ Variable } & Coefficient & Std. Error & t-Statistic & Prob. \\
\hline \hline C & 0.772949 & 0.377285 & 7.542640 & 0.0000 \\
ROE & 0.688443 & 0.117724 & 5.847948 & 0.0450 \\
DER & -0.241743 & 0.041099 & -5.881978 & 0.0470 \\
NPM & 0.618827 & 0.421137 & -1.469420 & 0.1461 \\
INFLASI & 0.739335 & 1.240222 & 0.596131 & 0.5530 \\
\hline \hline R-squared & 0.439195 & Mean dependent var & 1.027355 \\
Adjusted R-squared & 0.407600 & S.D. dependent var & 0.666368 \\
S.E. of regression & 23.60108 & Akaike info criterion & 9.223987 \\
Sum squared resid & 395.4777 & Schwarz criterion & 9.377325 \\
Log likelihood & -345.5115 & Hannan-Quinn criter. & 9.285268 \\
F-statistic & 13.90092 & Durbin-Watson stat & 0.598634 \\
Prob(F-statistic) & 0.000017 & & \\
\hline \hline
\end{tabular}

Source: Research data processed 2020 (Eviews Version 9) 
Fixed Effect Test

Table 4.3 Fixed Effect

Dependent Variable: DPR

Method: Panel Least Squares

Sample: 20142017

Periods included: 4

Cross-sections included: 19

Total panel (balanced) observations: 76

\begin{tabular}{crrrc}
\hline \hline Variable & Coefficient & Std. Error & t-Statistic & Prob. \\
\hline \hline C & 0.420051 & 0.151917 & 1.006687 & 0.0002 \\
ROE & 0.329278 & 0.630588 & 2.522175 & 0.0337 \\
DER & 0.046967 & 0.135161 & 1.747491 & 0.0296 \\
NPM & -1.725681 & 0.202746 & -1.434784 & 0.1572 \\
INFLASI & -0.932677 & 1.061673 & 0.878498 & 0.3836 \\
\hline \hline
\end{tabular}

Effects Specification

Cross-section fixed (dummy variables)

\begin{tabular}{lrll}
\hline R-squared & 0.798164 & Mean dependent var & 0.502355 \\
Adjusted R-squared & 0.615326 & S.D. dependent var & 13.66368 \\
S.E. of regression & 19.01826 & Akaike info criterion & 2.973498 \\
Sum squared resid & 191.6979 & Schwarz criterion & 7.678851 \\
Log likelihood & -317.9929 & Hannan-Quinn criter. & 7.255391 \\
F-statistic & 6.453197 & Durbin-Watson stat & 1.808323 \\
Prob(F-statistic) & 0.000000 & & \\
\hline \hline
\end{tabular}

Source: Research data processed 2020 (Eviews Version 9)

Random Effect Model Test

Table 4.4 Random Effect Model

Dependent Variable: DPR

Method: Panel EGLS (Cross-section

random effects)

Sample: 20142017

Periods included: 4
Cross-sections included: 19

Total panel (balanced) observations: 76

Swamy and Arora estimator of component variances

\begin{tabular}{|c|c|c|c|c|}
\hline Variable & Coefficient & Std. Error & t-Statistic & Prob. \\
\hline $\mathrm{C}$ & 0.732028 & 0.881229 & 2.781200 & 0.0000 \\
\hline ROE & 0.677549 & 0.164700 & 0.113838 & 0.0001 \\
\hline DER & 0.222025 & 0.054822 & -4.049936 & 0.0001 \\
\hline NPM & -0.948051 & 0.543420 & -1.744602 & 0.0854 \\
\hline INFLASI & -0.778050 & 1.004838 & -0.774304 & 0.4413 \\
\hline \multicolumn{5}{|c|}{ Effects Specification } \\
\hline & & & S.D. & Rho \\
\hline Cross-section random & & & 14.00264 & 0.3515 \\
\hline Idiosyncratic random & & & 19.01826 & 0.2485 \\
\hline \multicolumn{5}{|c|}{ Weighted Statistics } \\
\hline R-squared & 0.248040 & dependent va & & 28.66494 \\
\hline
\end{tabular}


Prob(F-statistic) 0.000395

\begin{tabular}{llll}
\hline & Unweighted Statistics & 0.502355 \\
R-squared & 0.426669 & Mean dependent var & 0.508767 \\
\hline \hline
\end{tabular}

Source: Research data processed 2020 (Eviews Version 9)

Chow Test

Table 4.5 Chow Test Result

Redundant Fixed Effects Tests

Equation: Untitled

Test cross-section fixed effects

\begin{tabular}{lrrr}
\hline Effects Test & Statistic & d.f. & Prob. \\
\hline \hline Cross-section F & 23.130021 & $(18,53)$ & 0.0006 \\
Cross-section Chi-square & 55.037216 & 8 & 0.0001 \\
\hline \hline
\end{tabular}

Cross-section fixed effects test

equation:

Dependent Variable: DPR

Method: Panel Least Squares

Sample: 20142017

\begin{tabular}{|c|c|c|c|c|}
\hline Variable & Coefficient & Std. Error & t-Statistic & Prob. \\
\hline $\mathrm{C}$ & 0.772949 & 0.377285 & 7.542640 & 0.0450 \\
\hline ROE & 0.688443 & 0.117724 & 5.847948 & 0.0100 \\
\hline DER & -0.241743 & 0.041099 & -5.881978 & 0.0200 \\
\hline NPM & 0.618827 & 0.421137 & -1.469420 & 0.1461 \\
\hline INFLASI & -0.739335 & 1.240222 & 0.596131 & 0.5530 \\
\hline R-squared & 0.439195 & \multicolumn{2}{|c|}{ Mean dependent var } & 1.027355 \\
\hline Adjusted R-squared & 0.407600 & \multicolumn{2}{|c|}{ S.D. dependent var } & 0.666368 \\
\hline S.E. of regression & 23.60108 & \multicolumn{2}{|c|}{ Akaike info criterion } & 9.223987 \\
\hline Sum squared resid & 39547.77 & \multicolumn{2}{|c|}{ Schwarz criterion } & 9.377325 \\
\hline Log likelihood & -345.5115 & \multirow{2}{*}{\multicolumn{2}{|c|}{$\begin{array}{l}\text { Hannan-Quinn criter. } \\
\text { Durbin-Watson stat }\end{array}$}} & 9.285268 \\
\hline F-statistic & 13.90092 & & & 0.598634 \\
\hline Prob(F-statistic) & 0.000017 & & & \\
\hline
\end{tabular}

Source: Research data processed 2020 (Eviews Version 9)

Hausman Test

Table 4.6 Hausman Test Result

Correlated Random Effects - Hausman Test

Equation: Untitled

Test cross-section random effects

\begin{tabular}{lrrr}
\hline Test Summary & Chi-Sq. Statistic & Chi-Sq. d.f. & Prob. \\
\hline \hline Cross-section random & 6.490450 & 4 & 0.0340 \\
\hline
\end{tabular}

${ }^{*}$ Cross-section test variance is invalid. Hausman statistic set to zero.

Cross-section random effects test comparisons:

\begin{tabular}{ccccc}
\hline \hline Variable & Fixed & Random & Var(Diff.) & Prob. \\
\hline ROE & 0.329278 & 0.677549 & 0.070516 & 0.0372 \\
DER & 0.046967 & 0.222025 & 0.015263 & 0.0265 \\
NPM & -1.725681 & -0.948051 & 1.151294 & 0.0686
\end{tabular}


INFLASI

$-0.932677$

$-0.778050$

0.117451

Source: Research data processed 2020 (Eviews Version 9)

\section{Analysis and Calculation}

Seeing the magnitude of the influence of Return On Equity, Debt to Equity Ratio, Net Profit Margin and Inflation as independent variables on the Dividend Payout Ratio as the dependent variable using the Fixsed Effect Model.

Here is a fixed effect model for variable regression of Return On Equity, Debt to Equity Ratio, Net Profit Margin and Inflation as independent variables on the Dividend Payout Ratio.

Table 4.7

Panel Data Regression Analysis Fixed Effect Model for ROE, DER, NPM, and Inflation against the DPR

Dependent Variable: DPR

Method: Panel Least Squares

Sample: 20142017

Periods included: 4

Cross-sections included: 19

Total panel (balanced) observations: 76

\begin{tabular}{crrrr}
\hline \hline Variable & Coefficient & Std. Error & t-Statistic & Prob. \\
\hline C & 0.420051 & 0.151917 & 1.006687 & 0.0002 \\
ROE & 0.329278 & 0.630588 & 2.522175 & 0.0337 \\
DER & 0.046967 & 0.135161 & 1.747491 & 0.0296 \\
NPM & -1.725681 & 0.202746 & -1.434784 & 0.1572 \\
INFLASI & -0.932677 & 1.061673 & 0.878498 & 0.3836 \\
\hline \hline
\end{tabular}

Effects Specification

\begin{tabular}{|c|c|c|c|}
\hline \multicolumn{4}{|c|}{ Cross-section fixed (dummy variables) } \\
\hline R-squared & 0.798164 & Mean dependent var & 0.502355 \\
\hline Adjusted R-squared & 0.615326 & S.D. dependent var & 13.66368 \\
\hline S.E. of regression & 19.01826 & Akaike info criterion & 2.973498 \\
\hline Sum squared resid & 191.6979 & Schwarz criterion & 7.678851 \\
\hline Log likelihood & -317.9929 & Hannan-Quinn criter. & 7.255391 \\
\hline F-statistic & 6.453197 & Durbin-Watson stat & 1.808323 \\
\hline Prob(F-statistic) & 0.000000 & & \\
\hline
\end{tabular}

Source: Research data processed 2020 (Eviews Version 9)

t-Test

1) The Effect of Return On Equity on Dividend Payout Ratio in LQ45 Non-Banking Companies

The results of testing panel data analysis partially show the results of the t-count as follows for the independent variable ROE is 2.522175 while the t-table with $\alpha=5 \%$ and $\mathrm{df}=(\mathrm{n}-\mathrm{k}) \rightarrow 76-4=72$, then $\mathrm{t}$-table $=1.66629$, so that the $\mathrm{t}$-count is smaller than the t-table (2.522175> 1.66629), so it can be concluded that the independent variable ROE has an influence on the dependent variable of the DPR. Then the probability value of ROE is smaller than the constant value $(0.0337<0.05)$, it can be said to be significant, thus it can be stated that the ROE variable has a significant influence on DPR.

2) The Effect of Debt To Equity Ratio on Dividend Payout Ratio in LQ45 NonBanking Companies

The results of the panel data analysis test partially show the results of t-count as follows for the independent variable DER is 1.747491 while the t-table with $\alpha=5 \%$ and $\mathrm{df}=(\mathrm{n}-\mathrm{k}) \rightarrow 76-4=72$, then $\mathrm{t}$-table $=1.66629$, so that the $\mathrm{t}$-count is smaller than the $\mathrm{t}-$ 
table (1.747491> 1.66629), so it can be concluded that the DER independent variable has an influence on the dependent variable DPR. Then the probability value of DER is smaller than the constant value $(0.0296<0.05)$, so it can be said to be significant, thus it can be stated that the DER variable has a significant influence on the DPR.

3) The Effect of Net Profit Margin on Dividend Payout Ratio in Non-Banking LQ45 Companies

The results of the panel data analysis test partially show the results of t-count as follows for the independent variable NPM is -1.434784 while the t-table with $\alpha=5 \%$ and $\mathrm{df}=(\mathrm{n}-\mathrm{k}) \rightarrow 76-4=72$, then $\mathrm{t}$-table $=1.66629$, so that the $\mathrm{t}$-count is smaller than the t-table $(-1.434784<1.66629)$, so it can be concluded that the independent variable NPM has no influence on the dependent variable of the DPR. Then the probability value of 0.1572 is greater than the constant value $(0.1572>0.05)$, it can be said to be insignificant, thus it can be stated that the NPM variable has no effect and is not significant to the DPR.

4) The Effect of Inflation on Dividend Payout Ratio in Non-Banking LQ45 Companies

The outcome of testing panel data analysis partially show resulting t-count as follows for the independent variable. Inflation is 0.878498 while t-table with $\alpha=5 \%$ and $\mathrm{df}=(\mathrm{n}-\mathrm{k}) \rightarrow 76-4=72$, then $\mathrm{t}$-table $=1.66629$, so that $\mathrm{t}$-count is smaller than $\mathrm{t}$-table $(0.878498<1.66629)$, so it can be concluded that the independent variable inflation has no effect on the dependent variable of the DPR. Then the probability value of 0.3836 is greater than the constant value $(0.3836>0.05)$, it can be said to be insignificant, thus it can be stated that the inflation variable has no effect and is not significant to the DPR.

F-Test

5) The effect of the variable ROE, DER, NPM, and Inflation on the Dividend Payout Ratio simultaneously (Test F) in Non-Banking LQ45 Companies.

The F statistical test basically shows whether all the independent variables in the model have a joint influence on the dependent variable (Kuncoro, 2011). This test is carried out to see the effect of the independent variable simultaneously on the dependent variable. This test is carried out with a degree of confidence of $5 \%$. The results of calculations using eviews are shown in table 4.11 , the calculated $F$ value is 6.453197 while the $F$ table with a level of $\alpha=5 \%$ and df1 $=(k-1) \rightarrow 4-1=3$ and df $2=$ $(n-k) \rightarrow 76-4=72$, the $F$ table is 2.50 .

Thus $\mathrm{F}_{\text {statistic }}>\mathrm{F}_{\text {table }}(6.453197>2.50)$ so $\mathrm{H} 0$ is accepted or rejected $\mathrm{H} 1$, hence that all the $X$ variables simultaneously have an influence on the $Y$ variable. Based on the probability value (Statistical prop from table 4.11 which is the same with 0.000000 thus $\mathrm{F}_{\text {statistics }}>0.05(0.000000<0.05)$ so that $\mathrm{H} 1$ is accepted or rejects $\mathrm{H} 0$. Based on this analysis, the conclusion that the variables ROE, DER, NPM, and Inflation simultaneously significantly influence on the DPR.

\section{Determination Coefficient Testing (Adjustted R-Square)}

the sample can represent the total population. the sample can represent the total population. Based on table 4.11, the amount of Adjustted R-Square $\left(R^{2}\right)$ is 0.798164 , it means that the sample can represent the total population of $79.82 \%$. This means that the sample in this regression is able to repres ent the total population of approximately $79.82 \%$ while $20.18 \%$ is influenced by other factors from outside the regression model and based on the table. Interpretation of the coefficient of determination has a very high level of influence. 


\section{Table 4.8}

The Results of the DPR Influence Panel Data Regression Test

\section{To Price Earning Ratio}

Dependent Variable: PER

Method: Panel Least Squares

Sample: 20142017

Periods included: 4

Cross-sections included: 19

Total panel (balanced) observations: 76

\begin{tabular}{lrllc}
\hline \multicolumn{1}{c}{ Variable } & Coefficient & Std. Error & t-Statistic & Prob. \\
\multicolumn{1}{c}{ DPR } & 18.22136 & 4.052503 & 4.496323 & 0.0000 \\
\hline \hline & 0.093147 & 0.075625 & 1.231701 & 0.0232 \\
\hline \hline Cross-section fixed (dummy & Effects Specification & & \\
\hline R-squared & 0.560726 & Mean dependent var & 22.97408 \\
Adjusted R-squared & 0.411686 & S.D. dependent var & 14.07499 \\
S.E. of regression & 10.79575 & Akaike info criterion & 7.817116 \\
Sum squared resid & 6526.698 & Schwarz criterion & 8.430467 \\
Log likelihood & -277.0504 & Hannan-Quinn criter. & 8.062241 \\
F-statistic & 3.762262 & Durbin-Watson stat & 2.120350 \\
\hline \hline Prob(F-statistic) & 0.000058 & & \\
\hline
\end{tabular}

Source: Research data processed 2020 (Eviews Version 9)

The panel data regression test results using the Fixed Effect Model have a constant value of 18.22136 while the regression coefficient for the DPR variable is 0.093147 , so the regression equation becomes:

\section{Test Path Analysis of Mediation Model}

$$
Y=18.22136-0.093147 \text { DPR }
$$

1) Effect of ROE on $Z$ through $Y$

The results of statistical tests show that the direct effect of ROE on PER and the indirect effect mediated by the DPR is as follows:

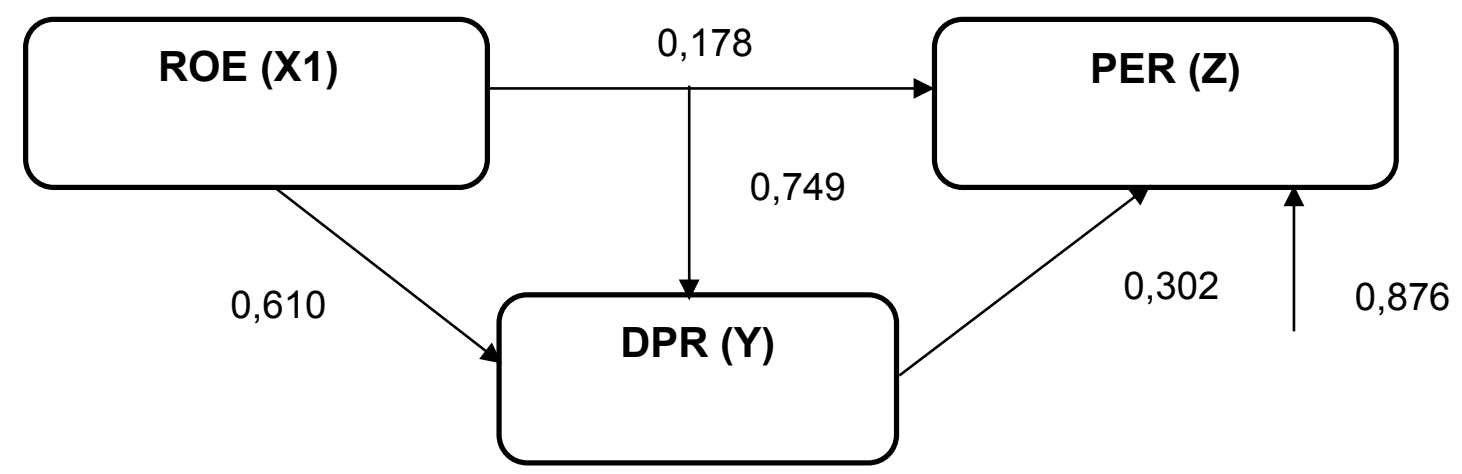

Figure 4.1 Relationship between ROE and PER through DPR

Figure 4.1 shows that ROE has an effect on PER (0.178), in the statistical test conducted previously it shows that ROE directly affects the DPR because the sig value is obtained that is smaller than 0.05 . X1 affects $Y(0.610)$, which shows a positive number, meaning that each ROE increases by one unit, the DPR will increase by 0.610 units, assuming the other independent variables are considered constant. Then $Y$ affects $Z(0.302)$ which shows a positive number, meaning that there is a significant effect of the DPR variable on Firm Value. Then for the indirect effect of ROE on Firm 
Value through the DPR is $(0.610 \times 0.302)=0.184$. To test the significance of this indirect effect using the Sobel test.

From the results of the calculation of the sobel test above, the $z$ value obtained is 1.728 , because the $z$ value obtained is $1.728<1.96$ (absolute $z$ value) with a significance level of $5 \%$, it significantly proves that there is no indirect effect of ROE on firm value mediated by DPR.

2) Effect of DER on $Z$ through $Y$

Based on the results of statistical tests, it is found that the direct effect of DER (X2) on PER $(Z)$ and the indirect effect mediated by the DPR $(Y)$ is as follows:

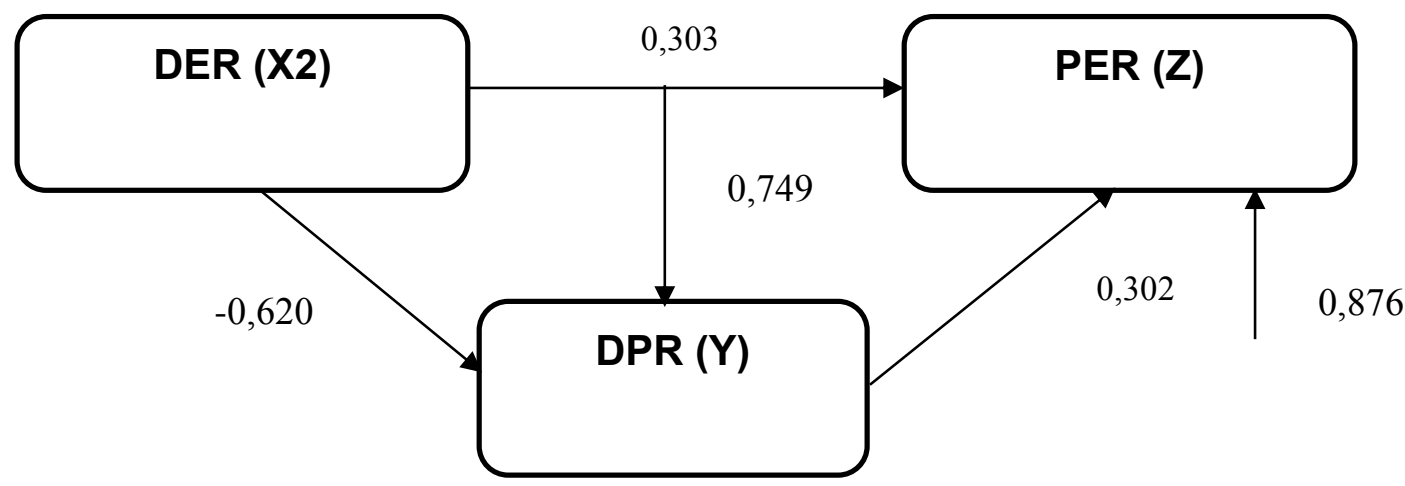

Figure 4.2 Relationship between DER and PER through DPR

From the calculation of the sobel test, the $z$ value obtained is -0.601 , because the $z$ value obtained is $-0.601<1.96$ (absolute $z$ value) with a significance level of $5 \%$, it significantly proves that there is no indirect effect of DER on firm value mediated by DPR.

3) Effect of NPM on $Z$ through $Y$

Based on the results of statistical tests, it is found that there is a direct effect of NPM (X3) on PER (Z) and the indirect effect mediated by DPR (Y) $\mathrm{i}$

$S$ as follows:

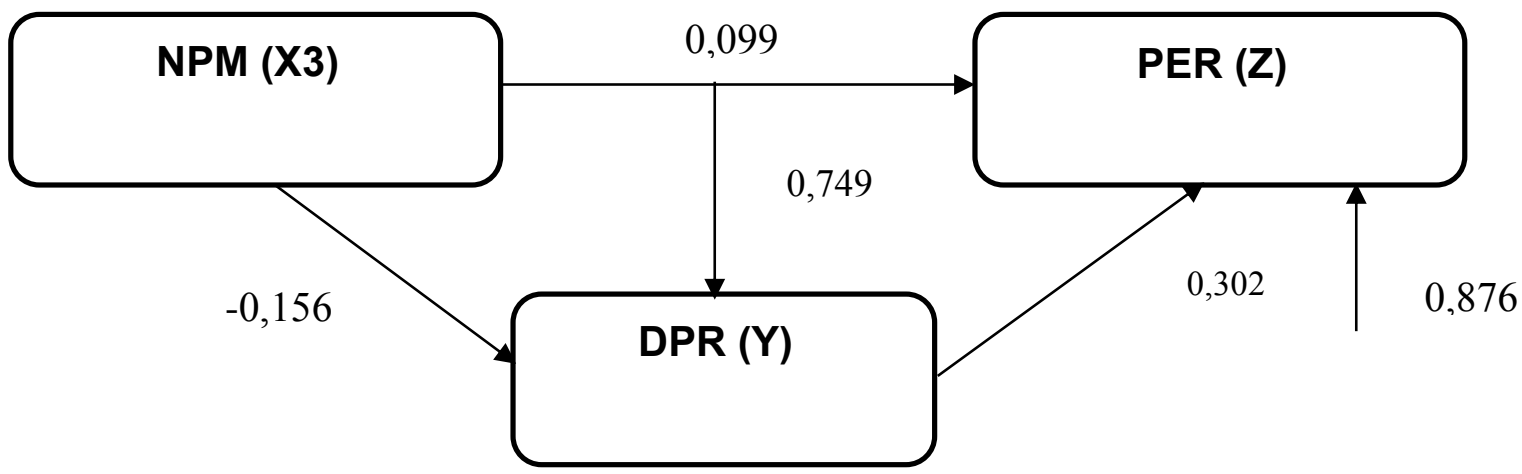

Figure 4.3 Relationship between NPM and PER through DPR

From the calculation of the sobel test, the $z$ value obtained is -3.688 , because the $z$ value obtained is $-3.688<1.96$ (absolute $z$ value) with a significance level of $5 \%$, it significantly proves that there is no indirect effect of NPM on firm value mediated by DPR.

4) Effect of Inflation on $Z$ through $Y$

Based on the results of statistical tests, it is found that there is a direct effect of inflation $(X 4)$ on PER (Z) and the indirect effect mediated by the DPR $(Y)$ is as follows: 


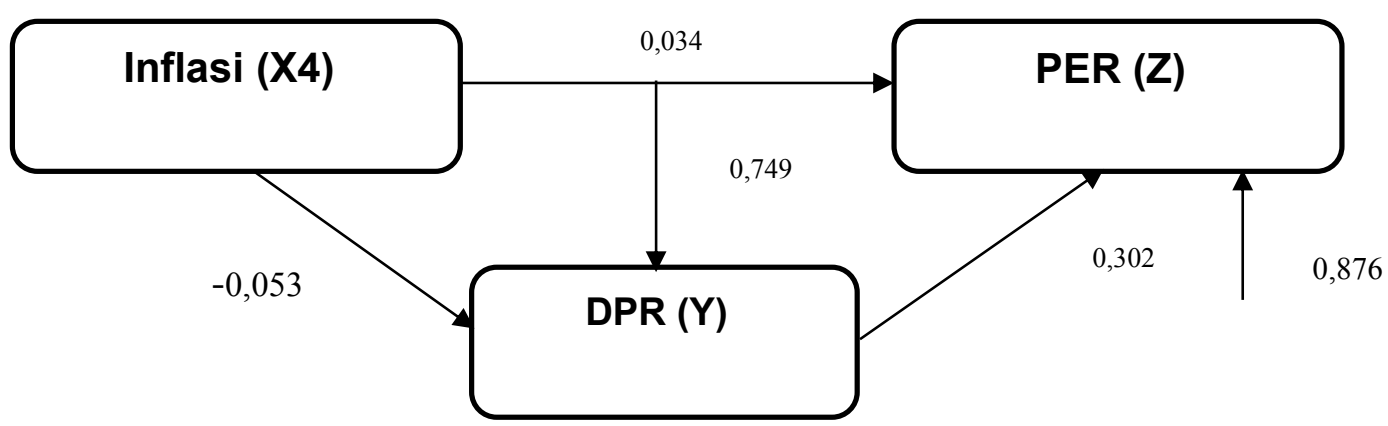

Figure 4.5 Relationship between Inflation and PER through

From the calculation of the sobel test, the $z$ value obtained is -5.127 , because the $z$ value obtained is $-5.127<1.96$ (absolute $z$ value) with a significance level of $5 \%$, it significantly proves that there is no indirect effect of NPM on firm value mediated by DPR.

\section{Results}

1) The Effect of Return on Equity on Dividend Payout Ratio in LQ45 Non-Banking Companies

$\mathrm{H} 1$ : the results of testing the hypothesis of the effect of Return on Equity on the Dividend Payout Ratio obtained t-count <t-table $(2.522175>1.66629)$ with a probability value (significance) of $0.0337<0.05$, then $\mathrm{H} 1$ is accepted and $\mathrm{H} 0$ is rejected. This shows that there is a significant and significant effect of the Return On Equity variable on the Dividend Payout Ratio in non-banking LQ45 companies. A positive sign is shown by the coefficient value of the Return On Equity variable, meaning that Return On Equity and Dividend Payout Ratio have a unidirectional relationship. The higher the Return On Equity value, the higher the Dividend Payout Ratio, and vice versa, the lower the Return On Equity, the lower the Dividend Payout Ratio value. decreasing will the company provide income to shareholders.

ROE, that explains the extent to which the company capacity to yield a profit which may be obtained by the shareholders (its net profit after interest and taxes divided by the number of their own capital)

2) The Effect of Debt To Equity Ratio on Dividend Payout Ratio in LQ45 Non-Banking Companies

H2: the results of hypothesis testing of the effect of Debt to Equity Ratio (DER) on Dividend Payout Ratio obtained t-count <t-table $(1.747491>1.66629)$ with a probability value (significance) of $0.0296<0.05$, then $\mathrm{H} 1$ is accepted and $\mathrm{H} 0$ is rejected. This shows that there is a significant influence and significant in either the ratio of debt to equity to the ratio of dividend payments on non-perbankan LQ45 company, a positive sign shown by the value of the variable the ratio of debt to equity, which means that the ratio of debt to equity its dividend payment links in line. The higher of DER, the higher the ratio of DPR, and vice versa, the lower the ratio of debt to equity, the lower the ratio of DPR.

The ratio of debt to equity is the debt ratio (leverage) of capital. This ratio measures how far the company is financed by debt where the higher the value of this ratio illustrates a symptom of being unfavorable for the company. Investors in investing do not see the importance of using debt or returning interest and principal debt because investors feel confident in managing company debt. 
3) The Effect of Net Profit Margin on Dividend Payout Ratio in LQ45 Non-Banking Companies

H3: the results of testing the hypothesis of the effect of Net Profit Margin on the Dividend Payout Ratio obtained by t-count <t-table $(-1.434784>1.66629)$ with a probability value (significance) of $0.1572>0.05$, then $\mathrm{H} 1$ is rejected and $\mathrm{HO}$ is accepted. This shows that there is no significant influence from the Net Profit Margin variable on the Dividend Payout Ratio in non-banking LQ45 companies, a negative sign which is shown by the coefficient value of the Net Profit Margin variable, meaning that the Net Profit Margin and Dividend Payout Ratio have an inverse relationship. The higher the Net Profit Margin value, the higher the Dividend Payout Ratio (DPR) value, and vice versa, the lower the Net Profit Margin, the lower the Dividend Payout Ratio value. This is due to the high gross profit, because this high gross profit shows that the company's performance is good and productive so that investor confidence increases to invest. The company which has stability can profit determining the extent to which DPR to investors and signifying the quality of corporate profits.

4) The Effect of Inflation on Dividend Payout Ratio in Non-Banking LQ45 Companies

$\mathrm{H} 4$ : the results of testing the hypothesis of the effect of inflation on the Dividend Payout Ratio obtained t-count $<\mathrm{t}$-table $(0.878498>1.66629)$ with a probability value (significance) of $0.3836>0.05$, then $\mathrm{H} 1$ is rejected and $\mathrm{H} 0$ is accepted. This shows that there is no and significant influence of the inflation variable on the Dividend Payout Ratio in non-banking LQ45 companies. A negative sign is shown by the coefficient value of the inflation variable, meaning that inflation and the Dividend Payout Ratio have an inverse relationship. a high inflation factor also allows an effect on the price of a stock. Inflation will reduce purchasing power and decrease the value of company assets (Permana and Sularto, 2008). A high inflation rate is usually associated with an overheated economy. This means that the condition of the economy slips into demand for products exceeds the capacity of adequate inventories of the product they, consequently prices tended to increase. That is too high inflation will also sent down purchasing power of money. In addition, high inflation can also reduce the level of real income from their investments (Kewal, 2012). This result can occur if the LQ45 company is able to respond to rising inflation by increasing the selling price of its products. So that there is no reason for companies to increase dividends.

5) The Effect of Return On Equity, Debt To Equity Ratio, Net Profit Margin and Inflation on Dividend Payout Ratio Simultaneously in LQ45 Non-Banking Companies

H5: The results of hypothesis testing of the effect of inflation on the Dividend Payout Ratio show that the simultaneous influence of ROE, DER, NPM, and Inflation on the DPR (F-Test). The test statistics $F$ basically indicates whether all the independent variable in the model have influence with him on the dependent variable (Kuncoro, 2011). This test is carried out to see the effect of the independent variable simultaneously on the dependent variable. This test is carried out with a degree of confidence of $5 \%$. The results of calculations using eviews are shown in table 4.11, the calculated $F$ value is 6.453197 while the $F$ table with a level of $\alpha=5 \%$ and df1 $=$ $(\mathrm{k}-1) \rightarrow 4-1=3$ and df2 $=(n-k) \rightarrow 76-4=72$, obtained $F$ table of 2.50 .

Thus $F_{\text {statistic }}>F_{\text {table }}(6.453197>2.50)$ so $\mathrm{HO}$ is accepted or rejected $\mathrm{H} 1$, it can be concluded that all the independent variables simultaneously have an influence on the dependent variable. Then it is also seen from the probability value (Statistical prop from table 4.11 which is equal to 0.000000 thus Fstatistics $>0.05(0.000000<0.05)$ so that $\mathrm{H} 1$ is accepted or rejects $\mathrm{H} 0$.Based on this analysis, it can be stated that the variables ROE, DER, NPM, and Inflation simultaneously There is a significant and significant influence on the DPR. the amount of Adjustted R-Square (R2) is 0.798164, it means that the sample can represent a total population of $79.82 \%$. This means that the sample in this regression is able to represent a total population of approximately 
79 , $82 \%$ while $20.18 \%$ are influenced by other factors from outside the regression model and based on the table, the interpretation of the coefficient of determination has a very high level of influence.

6) The Effect of Dividend Payout Ratio on PER in Non-Banking LQ45 Companies

$\mathrm{H} 4$ : the results of hypothesis testing of the effect of inflation on the Dividend Payout Ratio obtained t-count <t-table (18.22136> 2.50) with a probability value (significance) of $0.093147>0.05$, then $\mathrm{H} 1$ is rejected and $\mathrm{HO}$ is accepted. The increase in profit could be due to the good performance of the company and will influence investors to invest their funds in company shares. The increase in dividends paid is a signal to make an investment which results in an increase in PER. Changes in the DPR can affect PER (Husnan, 2013). An increase in this ratio illustrates the increase in the amount of dividends distributed. The increase in the amount of dividend payments by the company resulted in investors interested in investing which resulted in an increase in PER. An increase in this ratio illustrates the increase in the amount of dividends distributed. The increase in the amount of dividend payments by the company resulted in investors interested in investing which resulted in an increase in PER.

\section{E. CONCLUSION}

1. Return on Equity affects the Dividend Payout Ratio in LQ45 Non-Banking Companies.

2. Debt to Equity Ratio affects the Dividend Payout Ratio in Non-Banking LQ45 Companies.

3. Net Profit Margin (NPM) has no effect on the Dividend Payout Ratio in LQ45 NonBanking Companies.

4. Inflation has no effect on the Dividend Payout Ratio in Non-Banking LQ45 Companies.

5. Return On Equity, Debt To Equity Ratio, Net Profit Margin and Inflation simultaneously influence the Dividend Payout Ratio in LQ45 Non-Banking Companies.

6. Dividend Payout Ratio affects PER in Non-Banking LQ45 Companies.

7. There is no indirect effect between Return on Equity and PER in LQ45 Non-Banking Companies.

8. There is no indirect effect between the Debt to Equity Ratio and PER in LQ45 NonBanking Companies.

9. There is no indirect effect between Net Profit Margin on PER in LQ45 Non-Banking Companies.

10. There is no indirect effect between inflation on PER in LQ45 Non-Banking Companies.

\section{REFERENCES}

Brigham, F. E., \& Houston, F. J. 2015. Fundamentals of Financial Management (Concise $E d)$. South Western: Cengage Learning.

Hakim, L., Sunardi, N. (2017). Determinant of leverage and it's implication on company value of real estate and property sector listing in IDX period of 2011-2015. Man in India, 97(24), pp. 131-148.

Hanafi, M, M. dan Halim, A. 2017. Analisis Laporan Keuangan., Edisi tujuh. Yogyakarta: UPP AMP YKPN.

Hery. 2015. Analisis Laporan Keuangan. Edisi 1. Yogyakarta: Center For Academic Publishing Services. 
Husain, T., \& Sunardi, N. (2020). Firm's Value Prediction Based on Profitability Ratios and Dividend Policy. Finance \& Economics Review, 2(2), 13-26.

Husnan, S. 2013. Manajemen Keuangan Edisi Keempat. Yogyakarta: BPFE.

Irham, F. 2012. Pengantar Pasar Modal, Cetakan Pertama. Bandung: Alfabeta.

Irham, F. 2014. Analisa Kinerja Keuangan. Bandung: Alfabeta.

Kadim, A., Sunardi, N., \& Husain, T. (2020). The modeling firm's value based on financial ratios, intellectual capital and dividend policy. Accounting, 6(5), 859-870

Kasmir, 2014. Analisis Laporan Keuangan, Edisi Pertama, Cetakan Ketujuh. Jakarta: PT. Rajagrafindo Persada.

Kewal, S. S. 2012. Pengaruh Inflasi, Suku-Bunga, Kurs dan Pertumbuhan PDB terhadap Indeks-Harga Saham Gabungan. Jurnal Economia, 8 (1), 53-64.

Lestari, A. 2017. Ekonomi Moneter. Bogor: Penerbit in Media.

Martono, \& Harjito, A. 2011. Manajemen Keuangan. Edisi Kedua, Cetakan Pertama. Yogyakarta: EKONISIA.

Muhardi, Werner R. 2013. Analisis Laporan Keuangan Proyeksi dan Valuasi Saham. Jakarta: Salemba empat.

Permana, Y. \& Sularto, L. 2008. Analisis Pengaruh Fundamental Keuangan, TingkatBunga SBI dan Tingkat-Inflasi terhadap Pergerakan Harga Saham. Jurnal Ekonomi Bisnis, 2 (13), 103-111.

Sanjaya, R. 2019. The Influence of Ratio Analysis to The Dividend Payout Ratio and Its Impact on The Value of The Company Listed on The Malaysia Stock Exchange, Economic \& Accounting Journal, Vol. 2 (2) (95-103), Universitas Pamulang.

Silviana, C., dkk. 2014. Analisis Variabel-Variabel yang Mempengaruhi Kebijakan-Deviden (Studi pada Saham Indeks LQ-45 di BEI Periode 2010-2012). Jurnal Administrasi Bisnis (JAB). Vol. 15 No. 1. Fakultas Ilmu Administrasi, Universitas Brawijaya, Malang.

Sunardi, N. (2018). Kinerja Perusahan Pendekatan Du Pont System Terhadap Harga Dan Return Saham (Perusahaan yang tergabung dalam Industri Real Estate dan Properti yang terdaftar di Bursa Efek Indonesia Tahun 2011-2017). JIMF (Jurnal IImiah Manajemen Forkamma), 1(3).

Sunardi, N. (2019). Relevansi Intelectual Capital terhadap Harga dan Retun Saham di Industri Perbankan Pemerintah di Indonesia. JIMF (Jurnal IImiah Manajemen Forkamma), 3(1).

Sunardi, N., \& Febrianti, F. (2020). Likuiditas dan Kebijakan Hutang Pengaruhnya terhadap Kinerja Perusahaan dan Dampaknya Terhadap Nilai Perusahaan pada Industri Sektor Telekomunikasi di Indonesia. JIMF (Jurnal IImiah Manajemen Forkamma), 3(3).

Sunardi, N., \& Permana, R. D. I. (2019). Faktor-Faktor Yang Mempengaruhi Harga Saham Dan Dampaknya Pada Nilai Perusahaan (Studi Kasus pada Perusahaan Sub Sektor Pertambangan Minyak dan Gas Bumi yang Terdaftar di Bursa Efek Indonesia Tahun 2013-2017). JIMF (Jurnal IImiah Manajemen Forkamma), 2(2).

Tandelilin, E. 2010. Portofolio dan Investasi: Teori dan Aplikasi. Edisi 1. Yogyakarta: Kanisius. 